\title{
Oligarchs: \\ the past or the future of Russian capitalism?
}

\author{
Sergei Guriev and Andrei Rachinsky
}

July 2004

Sergei Guriev is the Human Capital Foundation Assistant Professor of Corporate Finance at the New Economic School, Moscow, Russia, and a Research Affiliate at the Centre for Economic Policy Research, London, UK. When writing this paper, he was on leave to the Department of Economics of Princeton University. Andrei Rachinsky is an economist at the Centre for Economic and Financial Research, Moscow, Russia. Their e-mail addresses are sguriev@nes.ru and arachinsky@,cefir.ru.

This paper builds on the authors' background paper "Ownership concentration in Russian industry" for the Worldbank's Country Economic Memorandum for Russia 2004. The authors are grateful to the whole CEM team, especially to David Brown, Dmitry Butrin, Vladimir Drebentsov, Christof Ruehl, and Mark Schaffer. We thank Daron Acemoglu, Erik Bergloef, Andrei Shleifer, Konstantin Sonin, Timothy Taylor, Ksenia Yudaeva, Katia Zhuravskaya, and Luigi Zingales, our colleagues at NES, CEFIR, and Princeton for helpful comments. We have also benefited from constructive criticisms and suggestions by Kakha Bendukidze, Yakov Pappe, Alexei Sokolov, Andrei Yakovlev. The views presented reflect the position of authors rather than that of the members of the World Bank Group. 
Russian industrial tycoons, or "oligarchs", are the quintessence of Russia's transition to capitalism. Any analysis of Russian economics and politics is incomplete without understanding their role. To the critics of Russian transition (Stiglitz, 2002, Goldman, 2004, Hoff and Stiglitz, 2004), the oligarchs represent the crony capitalism of 1990s, the unfair and illegitimate privatization, asset stripping, capital flight, capture of federal and state politics, and the enormous rise of inequality. The advocates of Russian reform (Boone and Rodionov, 2002, Aslund, 2004, Shleifer and Treisman, 2004) consider oligarchs to be the engine of institutional change and economic recovery since 1999 and the (only feasible) counterweight to the predatory and corrupt bureaucracy.

Understanding the role of oligarchs is crucial for many fundamental policy choices that will determine Russia's future. The degree of concentration in Russian economy is so high, that the policymakers' interest in oligarchs goes far beyond antitrust issues. First, the economic power amassed by the oligarchs automatically translates into political influence. This makes the oligarchs a crucial factor in the development of Russia's democratic institutions (or lack thereof). Second, the oligarchs control Russia's major exports and therefore determine Russia's standing in the global economy. Third, their role is crucial in establishing the most important foundation of modern capitalism: private property. As long as Russian median voter deems illegitimate the private property rights for a substantial part of the economy that the oligarchs control, it is hard to make democracy compatible with capitalism.

In this article we discuss available evidence on the degree of ownership concentration in Russian economy and its role in shaping economic and political institutions in Russia. We first lay out the facts on who the oligarchs are, what assets they control, and how well they run their assets. While we use a number of sources, our analysis is mostly based on a unique dataset built for the Country Economic Memorandum (CEM) for Russia, published by the Worldbank in 2004. This dataset is the first one to allow tracking concentration of control within individual companies, within industries, and at the level of the economy; moreover, we can compare performance of firms controlled by different types of owners. We then discuss the emergence of oligarchs and their role in Russian transition. We conclude by discussing policy options available and comparing modern Russia to other countries that have faced high concentration of national wealth.

Before we proceed, we must make a caveat about the term "oligarchs". To many readers, this term has a negative connotation. We certainly do not want to make a moral or legal judgment on Russia's richest businessmen. But as the term has become conventional for referring to Russian industrial tycoons, we use it for the readers' convenience without any particular preconceptions. 


\section{What we know about Russian oligarchs}

\section{Who are the oligarchs?}

High concentration of economic power in Russia has attracted public attention after implementation of the loans-for-shares scheme. In the middle of 1990s Russian government sold several valuable assets to private owners at a very low price for support of incumbent President in the elections of 1996 (Freeland, 2000). In its current meaning in Russia, the term "oligarch" denotes a large businessman ${ }^{1}$ who controls sufficient resources to influence national politics. ${ }^{2}$ It is not clear who first used the term oligarch to describe the newly emerged class of Russian tycoons. Kommersant (2003) refers to a pro-market politician Boris Nemtsov (then a governor of Nizhny Novgorod region, later to become a deputy prime-minister) and a journalist Alexander Privalov (Izvestiya daily, currently Expert weekly), both introducing the term in 1994-95.

There is no ultimate list of Russian oligarchs. Given the multi-layered and non-transparent ownership structure of Russian companies, compiling a list of oligarchs takes a lot of time and effort. On the other hand, any such list has to be constantly updated: there is substantial vertical mobility among Russia's richest. For example, out of seven or eight business groups that dominated Yeltsin's Russia, two were destroyed by the 1998 crisis (SBS and Inkombank), one took a hit but survived (Roskredit-cum-Metalloinvest), two have their leaders in exile (Berezovsky and Gusinsky) and one - in prison (Khodorkovsky). Other problems are related to the vagueness of the definition of oligarch. First, there are different views on how to measure tycoons' power rather than wealth (De Long, 1998, emphasizes this distinction with regard to US robber barons). Second, it is not clear whether to count public officials and CEOs of large public companies as oligarchs. On the latter issue we stick to the definition of oligarchs as of private owners.

The first list of oligarchs probably belongs to Boris Berezovsky (by all accounts, an oligarch himself) who, in his 1996 interview to Financial Times, named 7 bankers that controlled about 50\% of productive assets of Russian economy. Since then there have been numerous lists, some even endorsed by oligarchs themselves. As recently as in June 2003, Vladimir Potanin's Interros Holding Company supported a book by Kommersant (2003) that included the most comprehensive list of

\footnotetext{
${ }^{1}$ No oligarch ranking includes a female oligarch. The richest Russian businesswoman is probably Elena Baturina, the wife of the mayor of Moscow (Forbes Russia, 2004), but she is usually not considered an oligarch.

2 This is perfectly in line with the original meaning of the term introduced by Plato in "The Republic" and Aristotle in "Politics", as well as the modern understanding as in Ramseyer and Acemoglu. Russian elite's thinking of oligarchs has also been affected by Jack London's "The Iron Heel" anti-utopia on the rise of robber barons oligarchy that was widely publicized in Soviet Times.
} 
oligarchs with their profiles under an optimistic title "oligarch - that has a proud sound" (a parody of Soviet writer Maxim Gorky's "man - that has a proud sound").

All the oligarch rankings identify similar sets of individuals. Table 1 presents a list that we built based on the study of ownership concentration for the Worldbank's Country Economic Memorandum (CEM) for Russia, 2004 (Guriev and Rachinsky, 2004). The Worldbank's CEM project identified the structure of control for about 1700 largest firms in 32 industrial sectors and 13 service sectors of Russian economy in the summer of 2003. The sample accounts for a substantial part of Russian economy (e.g. it includes 1200 large industrial enterprises that produce more about $85 \%$ of output of the selected 32 industrial sectors, and more than $60 \%$ of Russia's total industrial output).

For the firms in the sample, we have tracked the degree of control up the pyramidal structures to construct a list of ultimate owners. In order to do so we have gone through more than five hundred intermediate owners, but have finally arrived at the list of almost seven hundred ultimate owners which included foreign firms, individuals, federal government or regional governments. We then created groups (partnerships) of private owners. ${ }^{3}$ We merged individual owners into a group whenever they appeared together as ultimate owners for every firm they had a non-trivial ownership of. This approach has helped to establish the basis for stable business groups (usually direct investment companies, registered as partnerships offshore with 2-7 partners). We also made some further adjustments. In particular, we merged the holdings of Vladimir Potanin and Mikhail Prohorov (who jointly own Norilsk Nickel, by far the most valuable asset of Potanin's Interros). We have also merged Popov, Melnichenko and Pumpiansky's holdings; even though these individuals started delineating their assets within a group already in 2003, the survey participants believed that in summer 2003 they still exercised joint control over the group's assets.

We ended up with 627 ultimate owners (432 in industry). In order to rank the owners by size, we calculated the total sales and employment controlled by each owner using a proportional rule. E.g., employment controlled by group $i$ is $\mathrm{E}_{i}=\Sigma_{j} \alpha_{i j} \mathrm{E}_{j}$, where $\alpha_{i j}$ is the share of control that group $i$ has over firm $j$, and $\mathrm{E}_{j}$ is the employment of firm $j$. As most oligarchs hold majority or supermajority stakes in their firms, our choice of proportional rather than majority rule provides a lower bound on concentration.

\footnotetext{
${ }^{3}$ The issue of joint voting/control is a serious methodological challenge for every study of concentration of ownership and control (Barca and Becht, 2001, pp.38-39). For example, consider the stakes controlled by Bill and Melinda Gates, Paul Allen, and Steven Ballmer in Microsoft in 1996 (LaPorta et al, 1999). All the four individuals disclose their stakes (38\% in total) separately and report that they do not have any commitment to vote in an agreed way. It seems reasonable to consider the group as a single blockholder. This is the approach followed by LaPorta et al. (1999), on the contrary, Becht (1999) assumes that Bill and Melinda Gates vote together, while Paul Allen, and Steven Ballmer may be separate owners.
} 
Table 1. Russian oligarchs. Source: Worldbank (2004) and Guriev and Rachinsky (2004).

\begin{tabular}{|c|c|c|c|c|c|}
\hline Seniorpartner(s) & $\begin{array}{l}\text { Holding company / firm, } \\
\text { major sector(s) }\end{array}$ & $\begin{array}{l}\text { Employment, } 000 \\
\text { (\% sample) }\end{array}$ & $\begin{array}{l}\text { Sales, } \mathrm{R} B \ln \\
(\% \text { sample) }\end{array}$ & Other rankings* & $\begin{array}{l}\text { RSPP bureau, head of } \\
\text { committee/task-force } \\
\text { (as of June 2004) }\end{array}$ \\
\hline Oleg Deripaska & $\begin{array}{l}\text { Base Element / RusAl, } \\
\text { aluminum, auto }\end{array}$ & $169(3.9 \%)$ & $65(1.3 \%)$ & $\begin{array}{l}\mathrm{P}, \mathrm{BR}, \mathrm{DS}, \mathrm{K}, \\
\mathrm{F}\end{array}$ & B, Railroad reform \\
\hline Roman Abramovich & $\begin{array}{l}\text { Millhouse / Sibneft, } \\
\text { oil }\end{array}$ & $169(3.9 \%)$ & $203(3.9 \%)$ & $\begin{array}{c}\mathrm{S}, \mathrm{BR}, \mathrm{DS}, \mathrm{K} \\
\mathrm{H}^{* *}, \mathrm{~F}\end{array}$ & \\
\hline Vladimir Kadannikov & $\begin{array}{l}\text { AutoVAZ, } \\
\text { automotive }\end{array}$ & $167(3.9 \%)$ & $112(2.2 \%)$ & $\mathrm{BR}, \mathrm{K}$ & \\
\hline $\begin{array}{l}\text { Sergei Popov, } \\
\text { Andrei Melnichenko, } \\
\text { Dmitry Pumpiansky }\end{array}$ & $\begin{array}{l}\text { MDM, } \\
\text { coal, pipes, chemical }\end{array}$ & $143(3.3 \%)$ & $70(1.4 \%)$ & F & $\begin{array}{l}\text { B, Financial markets } \\
\text { (Mamut**) }\end{array}$ \\
\hline Vagit Alekperov & $\begin{array}{l}\text { Lukoil, } \\
\text { oil }\end{array}$ & $137(3.2 \%)$ & $475(9.2 \%)$ & $\begin{array}{c}\text { S, P, BR, DS, } \\
\text { K, F }\end{array}$ & \\
\hline Alexei Mordashov & $\begin{array}{l}\text { Severstal, } \\
\text { steel, auto }\end{array}$ & $122(2.8 \%)$ & $78(1.5 \%)$ & BR, DS, F & $\begin{array}{l}\text { B, Customs and } \\
\text { WTO accession }\end{array}$ \\
\hline $\begin{array}{l}\text { Vladimir Potanin, } \\
\text { Mikhail Prokhorov }\end{array}$ & $\begin{array}{l}\text { Interros / Norilsk Nickel, } \\
\text { non-ferrous metals }\end{array}$ & $112(2.6 \%)$ & $137(2.6 \%)$ & $\begin{array}{l}\mathrm{B}, \mathrm{S}, \mathrm{P}, \mathrm{BR} \\
\mathrm{DS}, \mathrm{K}, \mathrm{F}\end{array}$ & $\begin{array}{l}\text { B, Social and labor } \\
\text { relations } \\
\left(\text { Eremeev }^{* *}\right)\end{array}$ \\
\hline Alexandr Abramov & $\begin{array}{l}\text { Evrazholding, } \\
\text { steel }\end{array}$ & $101(2.3 \%)$ & $52(1.0 \%)$ & F & B \\
\hline $\begin{array}{l}\text { Len Blavatnik, } \\
\text { Victor Vekselberg }\end{array}$ & $\begin{array}{l}\text { Access-Renova/TNK-BP, } \\
\text { oil, aluminum }\end{array}$ & $94(2.2 \%)$ & $121(2.3 \%)$ & $\mathrm{DS}, \mathrm{F}$ & B \\
\hline $\begin{array}{l}\text { Mikhail } \\
\text { Khodorkovsky }\end{array}$ & $\begin{array}{l}\text { Menatep/Yukos, } \\
\text { oil }\end{array}$ & $93(2.2 \%)$ & $149(2.9 \%)$ & $\begin{array}{l}\text { B, S, P, BR, } \\
\text { DS, K, H, F }\end{array}$ & $\begin{array}{l}\text { B, International } \\
\text { affairs }\end{array}$ \\
\hline Iskander Makhmudov & $\begin{array}{l}\text { UGMK, } \\
\text { non-ferrous metals }\end{array}$ & $75(1.7 \%)$ & $33(0.6 \%)$ & $\mathrm{K}$ & \\
\hline Vladimir Bogdanov & $\begin{array}{l}\text { Surgutneftegaz, } \\
\text { oil }\end{array}$ & $65(1.5 \%)$ & $163(3.1 \%)$ & $\begin{array}{l}\mathrm{P}, \mathrm{BR}, \mathrm{DS}, \mathrm{K}, \\
\mathrm{F}\end{array}$ & \\
\hline Victor Rashnikov & $\begin{array}{l}\text { Magnitogorsk Steel, } \\
\text { steel }\end{array}$ & $57(1.3 \%)$ & $57(1.1 \%)$ & & \\
\hline Igor Zyuzin & $\begin{array}{l}\text { Mechel, } \\
\text { steel, coal }\end{array}$ & $54(1.3 \%)$ & $31(0.6 \%)$ & & \\
\hline Vladimir Lisin & $\begin{array}{l}\text { Novolipetsk Steel, } \\
\text { steel }\end{array}$ & $47(1.1 \%)$ & $39(0.8 \%)$ & $\mathrm{F}$ & B \\
\hline $\begin{array}{l}\text { Zakhar Smushkin, } \\
\text { Boris Zingarevich, } \\
\text { Mikhail Zingarevich }\end{array}$ & $\begin{array}{l}\text { IlimPulpEnterprises, } \\
\text { pulp }\end{array}$ & $42(1.0 \%)$ & $20(0.4 \%)$ & & \\
\hline Shafagat Tahaudinov & $\begin{array}{l}\text { Tatneft, } \\
\text { oil }\end{array}$ & $41(1.0 \%)$ & $41(0.8 \%)$ & & \\
\hline Mikhail Fridman & $\begin{array}{l}\text { Alfa/TNK-BP, } \\
\text { oil }\end{array}$ & $38(0.9 \%)$ & $107(2.1 \%)$ & $\begin{array}{l}\mathrm{B}, \mathrm{S}, \mathrm{P}, \mathrm{BR} \\
\mathrm{DS}, \mathrm{K}, \mathrm{F}\end{array}$ & B, Judiciary reform \\
\hline Boris Ivanishvili & $\begin{array}{l}\text { Metalloinvest, } \\
\text { ore }\end{array}$ & $36(0.8 \%)$ & $15(0.3 \%)$ & $\mathrm{P}^{*}$ & $\begin{array}{l}\text { B, Land reform } \\
\left(\text { Kiselev**) }^{* *}\right.\end{array}$ \\
\hline Kakha Bendukidze & $\begin{array}{l}\text { United Machinery, } \\
\text { engineering }\end{array}$ & $35(0.8 \%)$ & $10(0.2 \%)$ & $\mathrm{BR}, \mathrm{K}$ & B, Budget and taxes \\
\hline $\begin{array}{l}\text { Vladimir } \\
\text { Yevtushenkov }\end{array}$ & $\begin{array}{l}\text { Sistema/MTS, } \\
\text { telecoms }\end{array}$ & $20(0.5 \%)$ & $27(0.5 \%)$ & $\begin{array}{l}\mathrm{S}, \mathrm{P}, \mathrm{BR}, \mathrm{DS}, \\
\mathrm{K}, \mathrm{F}\end{array}$ & $\begin{array}{l}\text { B, Industrial policy, } \\
\text { Pension reform } \\
\text { (Yurgens**) }\end{array}$ \\
\hline $\begin{array}{l}\text { David Yakobashvili, } \\
\text { Mikhail Dubinin, } \\
\text { Sergei Plastinin } \\
\end{array}$ & $\begin{array}{l}\text { WimmBillDann, } \\
\text { dairy/juice }\end{array}$ & $13(0.3 \%)$ & $20(0.4 \%)$ & & \\
\hline Total & & $1,831(42.4 \%)$ & $2,026(39.1 \%)$ & & \\
\hline
\end{tabular}




\section{CAPTION:}

Each entry lists the leading shareholder(s) in a respective business group, the name of the holding company or the flagship asset, and one or two major sectors. We report several individual per group only when there is equal or near equal partnership.

Ranking is based on employment in the sample and may therefore be different from actual, as the sample disproportionally covers assets of different oligarchs. Employment and sales are based on official firm-level data for 2001. The exchange rate was $\$ 1=29$ rubles.

RSPP stands for Russian Union of Industrialists and Entrepreneur, the leading lobbying organization for Russian business. B stands for RSPP Bureau membership (in total RSPP Bureau includes President and 24 members); we also list the RSPP committees/taskforces the particular oligarchs are in charge of (in total there are 17 committees/taskforces in RSPP).

* Other oligarch rankings:

B - Berezovsky's Group of Seven (Financial Times, 1996)

S - Classified as oligarchs in the "Sale of the Century" (Freeland, 2000, p. xv-xvii)

P - Pappe (2000)

BR - Boone and Rodionov (2002)

DS - Dynkin and Sokolov (2002)

K - Kommersant (2003)

H - Hoffman (2003)

F - Forbes (2004)

** Some of RSPP committee chairs have retired from active business

Mamut was MDM Board Chairman at the time of appointment at RSPP

Kiselev was Metalloinvest Board Chairman at the time of appointment RSPP

Eremeev was an Interros executive prior to the appointment at RSPP

Yurgens was a Sistema executive prior to the appointment at RSPP

Hoffman discusses Berezovsky rather than Abramovich. In 2000-2003, Abramovich took over most of

Berezovsky's assets in Russia as Berezovsky went into exile.

*** Khodorkovsky has remained a Bureau member and a Committee Chair even though he was in jail since Oct 2003. 
Table 1 includes 22 largest private domestic owners in this dataset. The threshold is as follows: either total annual sales revenues controlled by a particular group of owners are above 20 billion rubles (USD 700 million), or total employment controlled by the group are above 20 thousand people. In both sales and employment rankings, the $23^{\text {rd }}$ largest private owner was Ural Rakhimov, the son of Bashkir Republic's President, who held largest stakes in Bashkir firms but none outside the region.

The list in Table 1 was constructed from bottom up, by summing up control over a large sample of industrial enterprises. We did not have any list to start with. Yet, Table 1 is consistent with other oligarch rankings we are aware of. According to Forbes (2004), 19 individuals in Table 1 have personal wealth in excess of USD 1 billion; all but one groups have joint wealth of at least USD 0.7 bln. Our list is based on sales and employment rather than on wealth, as the former are easier to measure (most companies are not listed or not actively traded) and provide a good proxy for oligarchs' power.

Table 1 does not include the largest owners' interests in the industries outside our sample, so three clarifications are in order. First, we only account for a part of each conglomerate. Our comparisons with other studies of oligarch empires (in particular, with PSI Foundation, 2003) suggest that on average, we cover about 70\% of each group's sales and employment; this is not surprising given that our sample covers $60 \%$ of Russian industry. Second, our ranking of oligarchs may be distorted in favor of oligarchs who have stronger presence in the 45 sectors we cover. Third, our ranking excludes a couple of groups whose main assets are in industries outside our sample (e.g. Alexander Lebedev of National Reserve Corporation).

The background of individuals listed in Table 1 is very diverse. Most of them are very young: 9 of them are in their 30s, and 13 are in their 40s. The older oligarchs have come from Soviet-time nomenklatura, either managing the respective enterprises or working in government agencies supervising the enterprises. Insider privatization has helped them to reestablish their control over the enterprises. The younger entrepreneurs started from scratch in the late 1980s building their initial wealth during Gorbachev's partial reforms when co-existence of regulated and quasi-market prices created huge opportunities for arbitrage. In 1992, as price liberalization and privatization began, most of them owned leading trading companies, banks, and/or investment funds.

Each group in Table 1 controls assets in multiple regions and countries, and in several industries. Mostly, the oligarchs' conglomerates are horizontally and vertically integrated. Only Abramovitch, Deripaska, MDM group, and Potanin control major assets in unrelated industries, but even in their empires there is a single industry which accounts for most of the conglomerate's value. 
Contrary to common beliefs, only a handful of oligarchs owe their fortunes to the loans-for-shares auctions held in mid-1990s. The loans-for-shares are considered by the vast majority of Russian population (and now by the political elite) as the most scandalous episode of Russian privatization. In the classical loans-for-shares scenario, government appointed a commercial banker to run an auction that would allocate a controlling stake of a large natural resource enterprise in exchange for a loan to federal government that the latter never intended to repay. Not surprisingly, the auctioneer always awarded the stake to himself for a nominal bid (usually, slightly above a low reserve price) by excluding all outside bidders. The whole scheme was designed to consolidate the bankers' support for Yeltzin's reelection bid in 1996 (Freeland, 2000). The auctions were held before the elections, while the loan repayment was scheduled for after the elections. If Yeltzin lost to communists in 1996, the loans-for-shares results would be reversed.

The conventional loans-for-shares story fits Abramovich (in 1995-97, a junior partner of Berezovsky), Khodorkovsky, and especially Potanin. The other two winners were the oil sector insiders Alekperov and Bogdanov who obtained stakes in firms they already controlled. The other oligarchs acquired their assets either in the course of voucher privatization in the early 1990s or in the post-1998-crisis takeover wave. Some of the 22 largest owners have tried to participate in the loans-for-shares and even offered more competitive bids but were excluded by those in charge of respective auctions; some even raised their concerns in public (Freeland, 2000).

The track record of a few oligarchs could generally qualify as a success story of Russian reform, at least as conceived by its authors (Boycko et al., 1995). In early 1990s, Kakha Bendukidze consolidated a large number of vouchers, and then purchased controlling stake of his main industrial asset Uralmash in a voucher auction. In the course of 10 years he then built a large engineering company with modern corporate governance and shares listed in London. The Wimm-Bill-Dann shareholders David Yakobashvili, Sergei Plastinin and Mikhail Dubinin introduced a new productWestern style juice-to the Russian market; in 1992, they took a \$50,000 loan and leased a production line in a dairy plant in Moscow. They then took over the whole plant and other 13 dairy and juice plants around Russia, in 2002 they did an IPO at NYSE.

The examples above do illustrate that the outside privatization and entrepreneurship can succeed in Russia. In both cases, the entrepreneurs were neither industry nor government insiders. ${ }^{4}$ Ironically, these examples also prove that connections are more important: both groups are at the bottom of the list; both companies' market values are below $\$ 1$ billion. In the meanwhile, the loans-for-shares

\footnotetext{
${ }^{4}$ Neither of them even tried to bid for loans-for-shares. In March 1995, the day after the government meeting that first discussed the loans-for-shares program, Bendukidze told a journalist that “... loans-for-shares are an effort "to set up an oligarchy in the Russian economy" (Freeland, 2000).
} 
winners dominate the top of the list (especially if ranked by sales), and each of these groups is worth more than $\$ 10$ billion.

\section{Demand for institutional change vs. interest group politics}

Oligarchs have always recognized the importance of political influence. A few of them served in government in 1990s (two as high up as deputy prime ministers in charge of economic policy). When Putin announced in 2000 that oligarchs should be "equidistant" from government, the oligarchs have taken over Russian Union of Industrial and Entrepreneurs (RSPP) which has become a leading lobby group since then. Table 1 shows that oligarchs dominate RSPP's Bureau and main committees. RSPP's committees and taskforces led the way in rewriting and lobbying relevant legislation.

In a sense, RSPP lobbying activities are a tangible embodiment of demand for institutional change that Russian reformers had hoped for when they designed the sequencing of economic reform. RSPP's committees are supposed to lobby for low and transparent taxes, competent judiciary, efficient financial sector, reform of bureaucracy, reform of natural monopolies, Russia's accession to the World Trade Organization, development of small business, and even pragmatic foreign policy. On most of these issues, RSPP's position is indeed conducive to Russia's long term economic prosperity. Moreover, as other pro-market constituencies-small and medium size entrepreneurs and consumers-have failed to acquire any political weight, RSPP was effectively the only body to lobby for further economic reforms.

However, the intensity and therefore outcomes of RSPP's efforts vary widely across specific activities. RSPP was most successful in lowering taxes, liberalizing current and capital account, and promoting land reform. Some progress was achieved in administrative reform. RSPP was much less active in promoting banking reform and establishing a strong competition authority (fully in line with Rajan and Zingales, 2003, and Perotti and Volpin, 2003). RSPP members have been divided on Russia's WTO accession (Financial Times, 2002a). While the steel exporters were in favor of accession, the oligarchs that had stakes in protected sectors (such as automotive, insurance, banking) strongly opposed it. Also, some oligarchs had a temporary interest in delaying the accession. As WTO would result in harmonization of laws and regulations, it would bring an inflow of foreign direct investment and intensify competition for Russia's industrial assets. Given the lack of financial development, foreigners are the only serious competitors to oligarchs in Russian M\&A market. So the oligarchs were first interested in delaying the accession until they have completed their acquisitions. Currently, they are switching to support accession that would allow selling the assets to foreign investors at a higher price. 
The membership in RSPP's Bureau is even more important than control over its committees. In 2000-2003, RSPP Bureau members have regularly met with President Putin to discuss economic policy, reform of bureaucracy and other strategic issues. In the first of these meetings (July 2000) Putin promised to respect the oligarchs' property rights in exchange for their commitment to pay taxes and stay away from politics. This pact determined the ground rules of oligarchs' interaction with central and regional government for Putin's first term (2000-2004).

\section{What oligarchs control}

Table 1 confirms the conventional wisdom that oligarchs control a large part of Russian economy. In this Section we go one step further in understanding what sectors of the economy are controlled by the oligarchs and what implications it has for antitrust policy. We use the sample constructed in Worldbank (2004). The sample included largest firms in 45 sectors of the economy (including 32 industrial sectors, see Table 3). Sectors were narrowly defined (usually referring to a specific product market) and were drawn from industry, construction, and market services. ${ }^{5}$ The sectors were selected based on their size, the motivation being that the survey should cover as large a portion of the economy as possible. The 45 sectors represent $40 \%$ of Russian employment; in industry, the selected 32 sectors represent $50 \%$ of employment and $77 \%$ sales. It is important to note that the selection of sectors did not depend on concentration.

The second stage was to select the initial set of establishments and firms within the sectors. The selection criterion here was again size: the largest identified enterprises in each sector were targeted for the survey. In this case the motivation for using the size criterion was to be able to measure the degree of concentration in each chosen sector. In industry, our firms represented $35 \%$ employment and $85 \%$ sales of the selected 32 sectors.

In the third stage, economic and business journalists interviewed investment banks, consultancies, business advisors, information agencies and other institutions that are potential repositories of market knowledge. They identified (a) the main controlling owners of each firm and the portion of the firm they owned, and (b) any subsidiaries owned by the firms. This in turn generated new sets of firms to be investigated - subsidiaries and corporate owners. A chain would stop downward when a firm owns no subsidiaries, and would stop upwards when an "ultimate owner" or "controlling party" was identified. The resulting data were checked and supplemented with publicly accessible information.

\footnotetext{
${ }^{5}$ In industry, the sectors that were chosen were the largest 5-digit OKONKh (similar to 4-digit ISIC) industrial sectors by sales and employment that can be described as single "markets" or "sectors". A similar set of criteria was used for such sectors as construction and services. Several sectors were also chosen because of their strategic importance (e.g., banks and mass media).
} 
Table 2 presents the breakdown of ownership by categories. Indeed, oligarchs control about $40 \%$ of our sample.

\section{Table 2. Twenty two business groups control a greater share of our sample than either} regional and federal government combined, or more than all private owners combined.

The table presents total sales and employment of the firms in the sample controlled by each category of owners.

\begin{tabular}{l|cc}
\hline & Employment & Sales, RO00 \\
\hline \hline Oligarchs & $42 \%$ & $39 \%$ \\
Other private domestic & $22 \%$ & $13 \%$ \\
Foreign & $3 \%$ & $8 \%$ \\
Regions & $6 \%$ & $6 \%$ \\
Federal & $15 \%$ & $26 \%$ \\
No data & $12 \%$ & $8 \%$ \\
\hline \hline
\end{tabular}

Our methodology does not classify politicians, bureaucrats or executives of public companies as oligarchs. Unlike Hoffman (2003) and Kommersant (2003) we exclude Anatoly Chubais (CEO of nationwide electricity monopoly), Rem Vyakhirev (former CEO of Gazprom, the world's largest producer of natural gas), or Yuri Luzhkov (Mayor of Moscow). We assume that large companies with majority stakes of federal government are ultimately controlled by the federal government, even if most decisions are made by incumbent management. A good example of Kremlin's grip on power was the replacement of once-omnipotent Vyakhirev and his team shortly after Putin's election. ${ }^{6}$ We have not merged regional governments with private owners that are related with regional officials. For example, Moscow mayor's wife Elena Baturina is considered to be a separate private owner different from the Moscow City Government, and so are Vice-Mayors of the Moscow City wherever they own firms individually. Similarly, Ural Rakhimov is also considered to be a private owner, rather than a representative of Bashkir regional government headed by his father.

Table 3 presents the share of sales controlled by oligarchs in each sector. Again, to provide a conservative estimate for concentration, we used a proportional rule. E.g., the share of sales

\footnotetext{
${ }^{6}$ Forbes (2004) lists Vyakhirev as a billionaire presuming that he still keeps a large stake in the Gazprom. It is alleged though that he was forced to sell his shares when he was fired (Latynina, 2004). The federal government proved its credibility by the imprisonment of Yakov Goldovsky (CEO of Sibur, Gazprom's subsidiary) who was released only when he returned the assets he tunneled from Gazprom.
} 
controlled by oligarchs in sector $k$ would be $\Sigma_{i} \Sigma_{j} \alpha_{i j} \mathrm{~S}_{j k} / \mathrm{S}_{k}$ where $\alpha_{i j}$ is the share of control that oligarch $i$ has over firm $j$, and $\mathrm{S}_{j k}$ is the output of firm $j$ in this particular sector, $\mathrm{S}_{k}$ is the total output of sector $k$ (including firms that are not in the sample).

The Table suggests that oligarch dominate the largest industrial sectors, in particular natural resources and automotive. While we don't have firm-level value-added data, Worldbank (2004) estimated value added by sector, and arrived at the conclusion that the sectors controlled by oligarchs are exactly the ones that add more value added per unit of output. The fact that oligarchs control 39\% of sales probably implies that they control an even higher share of value added.

The only large sectors not controlled by oligarchs are natural gas, energy, and manufacture of machinery. The gas and energy sectors are dominated by federally owned monopolies Gazprom and RAO UES; machinery production is a diverse sector which is populated by defense production (controlled by federal government), oligarch firms and smaller firms controlled by non-oligarch private domestic owners.

\section{Oligarchs and market power}

Do oligarchs hold excessive market power in the sectors that they control? Our dataset allows calculating concentration ratios based on market shares of individual owners rather than market shares of establishments. Table 3 presents CR4 and Herfindahl-Hirschman Index for each sector. Indeed, the sectors controlled by oligarchs are the ones that are highly concentrated. However, these are also the sectors that are subject to global competition. Let us consider the ten sectors where oligarchs control more than 20\% sales. Except for ore and automotives, all these sectors sell to global market: they export 30\%-90\% of their output; actually, these sectors account for half of total Russian exports. The first exception proves the rule. Ore production is mostly owned by oligarchs' vertically integrated conglomerates where ore is an input.

The second exception (automotive sector) is on the contrary a classical example of interest groups politics. Russian cars are not internationally competitive; moreover, even given high import duties, import penetration is $25 \%$. The industry has always been protected (the largest carmaker's CEO Vladimir Kadannikov served in 1990s as the first deputy prime minister). However, as in 2000 Oleg Deripaska has consolidated his control over the second largest carmaker and almost all of the bus and truck production, the lobbying for even stronger protection reached new heights. The lobbyists managed to install prohibitive tariffs on imports of 7+ years old cars and high tariffs on 3-7 year old cars (Moscow Times, 2003). Russian cars are priced in the range of $\$ 4-8$ thousand; the new barriers were equivalent to giving Russian carmakers a slack of $\$ 2-4$ thousand per car. 


\section{Table 3. Oligarchs control largest industrial sectors except for natural gas and energy.}

The table presents the share of sales controlled by oligarchs in 32 industrial sectors sorted by size. The last two columns present concentration ratios: CR4 (the share of four largest owners in the sales of the sector) and Herfindahl-Hirschman Index (the sum of squared shares of all owners in the industry). CR 4 is reported in $\%$ and ranges from 0 to $100 \%$; HHI is reported in $\%$ squared, and ranges from 0 to 10,000 .

The total output of the 32 sectors (R 4,500 billion) represented $76.5 \%$ of Russia's industrial output and $50 \%$ GDP.

\begin{tabular}{|c|c|c|c|c|}
\hline Sector & $\begin{array}{c}\text { Sales 2001, } \\
\text { Ruble billion }\end{array}$ & $\begin{array}{c}\text { Oligarchs' } \\
\text { share in sales }\end{array}$ & $C R 4$ & $H H I, \% \%$ \\
\hline Oil & 1256 & $72 \%$ & $59 \%$ & 1,347 \\
\hline Natural gas & 579 & $1 \%$ & $94 \%$ & 8,655 \\
\hline Energy & 499 & $8 \%$ & $49 \%$ & 1,736 \\
\hline Ferrous metals & 275 & $78 \%$ & $66 \%$ & 1,180 \\
\hline Automotive & 225 & $71 \%$ & $71 \%$ & 2,365 \\
\hline Machinery & 209 & $12 \%$ & $12 \%$ & 51 \\
\hline $\begin{array}{l}\text { Non-ferrous metals } \\
\text { (except aluminum) }\end{array}$ & 154 & $92 \%$ & $95 \%$ & 6,250 \\
\hline Milk & 100 & $18 \%$ & $23 \%$ & 215 \\
\hline Pulp and paper & 93 & $30 \%$ & $41 \%$ & 646 \\
\hline Coal & 89 & $48 \%$ & $47 \%$ & 691 \\
\hline Aluminium & 84 & $80 \%$ & $90 \%$ & 2,274 \\
\hline Construction Materials & 82 & $6 \%$ & $32 \%$ & 385 \\
\hline Jewelry & 74 & $0 \%$ & $87 \%$ & 2,666 \\
\hline Meat & 69 & $16 \%$ & $29 \%$ & 299 \\
\hline Fertilizers & 61 & $46 \%$ & $66 \%$ & 1,350 \\
\hline Beer & 59 & $2 \%$ & $57 \%$ & 1,171 \\
\hline Tobacco & 59 & $0 \%$ & $91 \%$ & 3,121 \\
\hline Bakery & 58 & $0 \%$ & $5 \%$ & 11 \\
\hline Rubber & 51 & $4 \%$ & $65 \%$ & 1,291 \\
\hline Confectionary & 50 & $0 \%$ & $59 \%$ & 1,179 \\
\hline Timber & 48 & $5 \%$ & $8 \%$ & 32 \\
\hline Vodka & 45 & $14 \%$ & $33 \%$ & 384 \\
\hline Fish & 42 & $0 \%$ & $22 \%$ & 202 \\
\hline Mill & 40 & $5 \%$ & $14 \%$ & 95 \\
\hline Pipes & 34 & $55 \%$ & $85 \%$ & 3,541 \\
\hline Ore & 30 & $73 \%$ & $59 \%$ & 1,190 \\
\hline Tyre & 28 & $10 \%$ & $64 \%$ & 1,338 \\
\hline Pharmaceutical & 28 & $17 \%$ & $37 \%$ & 446 \\
\hline Cable & 23 & $15 \%$ & $34 \%$ & 411 \\
\hline Poligraphy & 22 & $2 \%$ & $38 \%$ & 659 \\
\hline Furniture & 20 & $3 \%$ & $23 \%$ & 206 \\
\hline Non-alcoholic drinks & 18 & $0 \%$ & $62 \%$ & 1,610 \\
\hline Total & 4500 & $39 \%$ & & \\
\hline
\end{tabular}


A byproduct of this lobbying effort was a postponement of Russia's WTO accession. As WTO members required lowering import duties for cars, the automotive lobby launched an aggressive (and a very successful) anti-WTO campaign. Even though WTO succession was declared by government and President a priority in economic policy already in 2000, Russia is still not a member of WTO.

Except for the automotive sector, there seems to be no concern for oligarchs to have excessive market power. Also, although their conglomerates are large by Russian standards, they are certainly not excessive by global standards. Some oligarchs are important global players in their industries (especially in oil and metals), but none is a market leader. This is not surprising as these industries are the ones with huge economies of scale. ${ }^{7}$ Russia therefore does not need antitrust policies aiming at breaking up oligarchs' companies. The competition policy must assure the level ground field for all owners disregard to their size and political influence - the "political antitrust" (Rajan and Zingales, 2003).

\section{Performance}

Optimistic observers of Russian economy believe that even if emergence of oligarchs is costly for equality and democracy, concentration of ownership in private hands is good for economic efficiency. Do oligarchs improve performance of the firms they control? In theory, there can be arguments both for and against superior performance of oligarchs. First, the "conglomerate discount" literature (e.g. Scharfstein and Stein, 2000) shows that large conglomerates should be less efficient than standalone firms since they are likely to suffer from multi-layered agency problems. On the other hand, vertical integration can mitigate hold-up problems that arise due to high specificity. This argument is certainly relevant in Russia; Blanchard and Kremer (1997) show that specificity was one of the major factors behind output collapse in early Russian transition. Many oligarch empires have been built to overcome the hold-up problems: all Russian major oil companies are vertically integrated, most steelmakers own sources of coal and ore etc.

Boone and Rodionov (2002) argue that oligarchs' performance should be superior as they have successfully overcome the separation of ownership and control (mostly by diluting/expropriating outside investors). Oligarchs that concentrated majority and supermajority of both control and cash flow rights in their firms should have perfect incentives for restructuring the companies rather than for diverting cash flows and stripping the assets. However, this argument does not have to imply that oligarchs should outperform other private owners. Indeed, what matters is concentration of

\footnotetext{
${ }^{7}$ These are exactly the sectors where large business empires originated in many countries in the late $19^{\text {th }}$ century and the early $20^{\text {th }}$ century including the US (DeLong, 1998), Japan (Morikawa, 1992), and Sweden (Hogsfeldt, 2003).
} 
ownership/control within company, rather than a very high share of national wealth accumulated in a few hands (e.g. in continental Europe, at the level of a firm, control is concentrated, but different firms are controlled by different owners, Faccio and Lang, 2002). We have compared the degree of control by the largest owner in companies controlled by oligarchs and non-oligarch private owners. In our sample, oligarchs do control a higher share on average (79\% vs $74 \%)$; the difference is statistically significant but not necessarily economically important; the average degree of control by smaller owners over their companies is also very high. In full accordance with law and finance view (LaPorta et al., 1998) poor protection of minority shareholders rights resulted in consolidation of control within most Russian companies. Smaller owners are not investors that hold small stakes in large companies; rather, they hold large stakes in small companies.

Another source of oligarchs' relative superior performance could be the economies of scale due to Russia's institutional environment. In Russia, size matters for at least two reasons. First, there are missing markets, and, in particular, financial markets. As Rajan and Zingales (2003) argue, larger firms benefit from underdevelopment of financial markets. Costly access to finance effectively serves as an entry barrier for smaller firms; this in turn increases oligarchs' profits (Acemoglu, 2003). Second, Russia lacks rule of law; in particular, it is hard to resist political intervention and the predatory "grabbing hand" of federal and local governments. Larger conglomerates are certainly more effective in influencing judicial and political decisions and protecting their property from bureaucratic predation (Grossman and Helpman, 1994, Sonin, 2003, Yakovlev and Zhuravskaya, 2003, Kumar et al., 2003).

An empirical test of the theories above is a challenge. It does not suffice just to compare performance indicators of oligarch controlled firms to those of the rest of the economy. ${ }^{8}$ First, as we will see below, the rest of the economy is not homogeneous, and different categories of nonoligarch owners differ greatly in terms of performance (foreign owners outperform domestic private owners who in turn outperform state enterprises). Second, oligarch firms are not evenly distributed across the economy; they are concentrated in a few sectors that experienced a very different set of market conditions and technological shocks. E.g. in 1999-2004 relative prices have been extremely favorable to oil companies but much less so to aircraft makers. Controlling for industry is also very important because of size. In our sample, oligarch control firms in industries where average firm is large, once controlling for industry, their firms are the same as those controlled by other private domestic owners (within the sample).

\footnotetext{
${ }^{8}$ PSI Foundation (2003) concludes that labor productivity in oligarch firms is about 4 times as high as the economywide average. We have been able to reproduce this result by comparing oligarch firms and all other Russian industrial enterprises without controlling for industry, region, size etc.
} 
Boone and Rodionov's argument is based on the logic of the "conglomerate discount" literature that has compared stock market valuation of firms within and outside diversified conglomerates (Lang and Stulz, 1994). Given that Russian stock market only includes tens of firms, with a handful in each industry (except for regional utilities and regional telecom companies both controlled by the state), Boone and Rodionov necessarily resort to case studies. In particular, they discuss the experience of Khodorkovsky's Yukos Oil Company. Until very recently Yukos has been a showcase of oligarchs' outstanding performance both in raising internal efficiency and improving transparency and corporate governance. Since the end of 1999 (when the company was ranked among the worst violators of outside investor rights, Black, 2001) to its high point in 2003, Yukos share price grew by the factor of 30 ; at its peak it accounted for $25 \%$ of Russia's stock market valuation. However, such a stellar performance may be an isolated case and does not provide systematic evidence of oligarchs' superior performance. We have compared 2002 and 2003 stock market returns for companies controlled by the oligarchs (Table 1) to the returns on other Russian stocks and found no significant differences. Also, there is no significant difference in corporate governance ratings (we used ratings by Brunswick and by Institute for Corporate Law and Governance). While oligarchs certainly led the way in improving corporate governance and raising market capitalization in 2000-01, other listed firms have already caught up with them.

Russian stock market is narrow, and most of the stocks are not actively traded. Using stock market returns to evaluate performance is therefore problematic. For any reasonable sample size, one has to turn to accounting data. In Guriev and Rachinsky (2004) and Worldbank (2004) we use firm-level data on 1200 industrial firms from Russian Industrial Enterprise Registry - the official census of Russian industrial firms. We largely follow the approach of Schoar (2002) and evaluate the effect of ownership structure on productivity (see also a survey of similar work on effects of privatization in Megginson and Netter, 2001). Our main equation estimates the effect of controlling owner's type on the total factor productivity (TFP) growth:

$$
\log \left(\mathrm{Y}_{\mathrm{i}, 2002} / \mathrm{Y}_{\mathrm{i}, 2001}\right)=\alpha+\beta \log \left(\mathrm{K}_{\mathrm{i}, 2002} / \mathrm{K}_{\mathrm{i}, 2001}\right)+\gamma \log \left(\mathrm{L}_{\mathrm{i}, 2002} / \mathrm{L}_{\mathrm{i}, 2001}\right)+\lambda^{\prime} \text { control_type } \mathrm{i}_{\mathrm{i}}+\mu^{\prime} \text { sector }_{\mathrm{i}}+\boldsymbol{v}^{\prime} \text { region }_{\mathrm{i}}+\mathrm{e}_{\mathrm{i}}
$$

Here $i$ is the firm's index, $Y$ is the firm's output, $K$ is capital (book value of fixed productive assets),

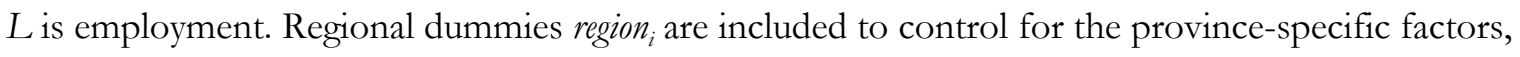
e.g. for price level and therefore wage differentials. Sector dummies sector $r_{i}$ indicate one of 32 industrial sectors (Table 3) and help to control for changes in relative prices, technological and other industry-specific shocks. Also, once we control for industry, it is likely that regressions for output $Y$ would provide results similar to those for value added; unfortunately, due to omnipresent VAT avoidance, there are no reliable firm-level data on value added in Russia. Most importantly, sector dummies at least partially mitigate the selection bias. As shown above, oligarchs tend to control 
firms in more attractive industries, so without industry dummies, the selection bias would certainly give oligarchs a substantial advantage.

Our main focus is on the control_type $e_{i}$ which is the dummy for the type of controlling owner. We distinguish between "oligarchs", "foreign owners" (usually large multinationals), "federal government", "regional governments", “other private domestic owners" (omitted category), and "no controlling owner". We have tried different definitions of "controlling owner"-from the type of largest controlling shareholder to the one who controls $50 \%$ or more-but they all provide similar results. The concentration of control within firms is very high (only in 5\% firms the largest owner controls less than $25 \%$ ). We have also checked for the effect of the degree of control, but also turned out insignificant; apparently, there is too little variation in the degree of control in our sample.

The regression results are presented in Table 4. ${ }^{9}$ In 2002, the oligarchs outperformed other private Russian owners by about $9 \%$ in terms of TFP growth. The only more productive owner type was foreign owners (10.5\% difference). The state-owned firms did not perform well. The firms controlled by federal and especially regional governments firms lagged behind, although the difference from non-oligarch domestic private firms was not significant. The latter result may be due to the fact that we classified firms controlled by relatives of regional governors as private; a proper identification of all such firms would however be an effort beyond this paper's focus on oligarchs.

The oligarchs and foreign owners do not raise productivity just by shedding excess labor. ${ }^{10}$ Our results (Table 4, columns 4-6) suggest that there is no significant difference in employment changes across owner types. Rather, the oligarchs have managed to produce more with the same amount of inputs.

The results for productivity levels (Table 5) are different. Foreign owners are significantly more productive than other owners. Oligarchs' current productivity is the same as other domestic owners'. This may reflect the fact that oligarchs' firms initially lagged their counterparts but oligarchs have successfully restructured them.

Columns 4-7 in Table 5 compare profits and wages by owner categories. Relative to other private owners, oligarchs do receive higher gross profits controlling for size and even for past profits. But

\footnotetext{
${ }^{9}$ We only present the main results. See Guriev and Rachinsky (2004) for robustness checks and alternative specifications. Results are robust to controlling for size or past productivity levels in TFP growth regressions. In the regressions with investment over the period of 2000-02 or 1999-2002 (in some specifications oligarchs turn out to be investing more but these results are not robust). The effect of degree of control on productivity is not significant.

10 The excess labor problem is certainly relevant for oligarchs as well as for other privatized firms. In private communications with authors, executives of several oligarchs' conglomerates acknowledged the need for cutting their employment by one half to even two thirds to become competitive with global leaders in their industry. However, political constraints certainly preclude drastic employment changes.
} 
the profits do not come at the expense of workers: the wages are not lower (even higher although the difference is not significant). Again, profits and wages may be misreported to reduce taxes but there seems no particular reason why the degree of manipulation should be owner-specific rather than industry- or region-specific.

We have also tried to estimate productivity differences in previous years starting with 1999. We did not find any significant differences between oligarch-controlled and other firms in terms of productivity growth in those years. As for productivity levels, the oligarch firms, if anything, were less productive in 2001 and before than others. Given that our ownership data refer to June 2003, there can be two potential explanations for the difference between results for 2002 and previous years. If we assume that ownership has not changed much in 2001-2003, then our 2001 regressions did compare firms within and outside oligarch groups. In this case, it may just be the argument brought up by Boone and Rodionov (2002): it just takes a long time to consolidate ownership and restructure. So results of restructuring were not yet tangible before 2002, and only now are starting to show up.

If we take an alternative assumption that a substantial part of oligarch holdings was purchased after 2001 then pre-2002 regressions point at firms that were not yet within oligarch groups but only joined them later. This implies that oligarchs have taken over the poorly performing firms and turned them around.

In both cases, the evidence is consistent with the view that oligarchs do manage their firms better, and almost as well as foreign owners. 
Table 4. Oligarchs outperform other Russian owners in terms of productivity growth.

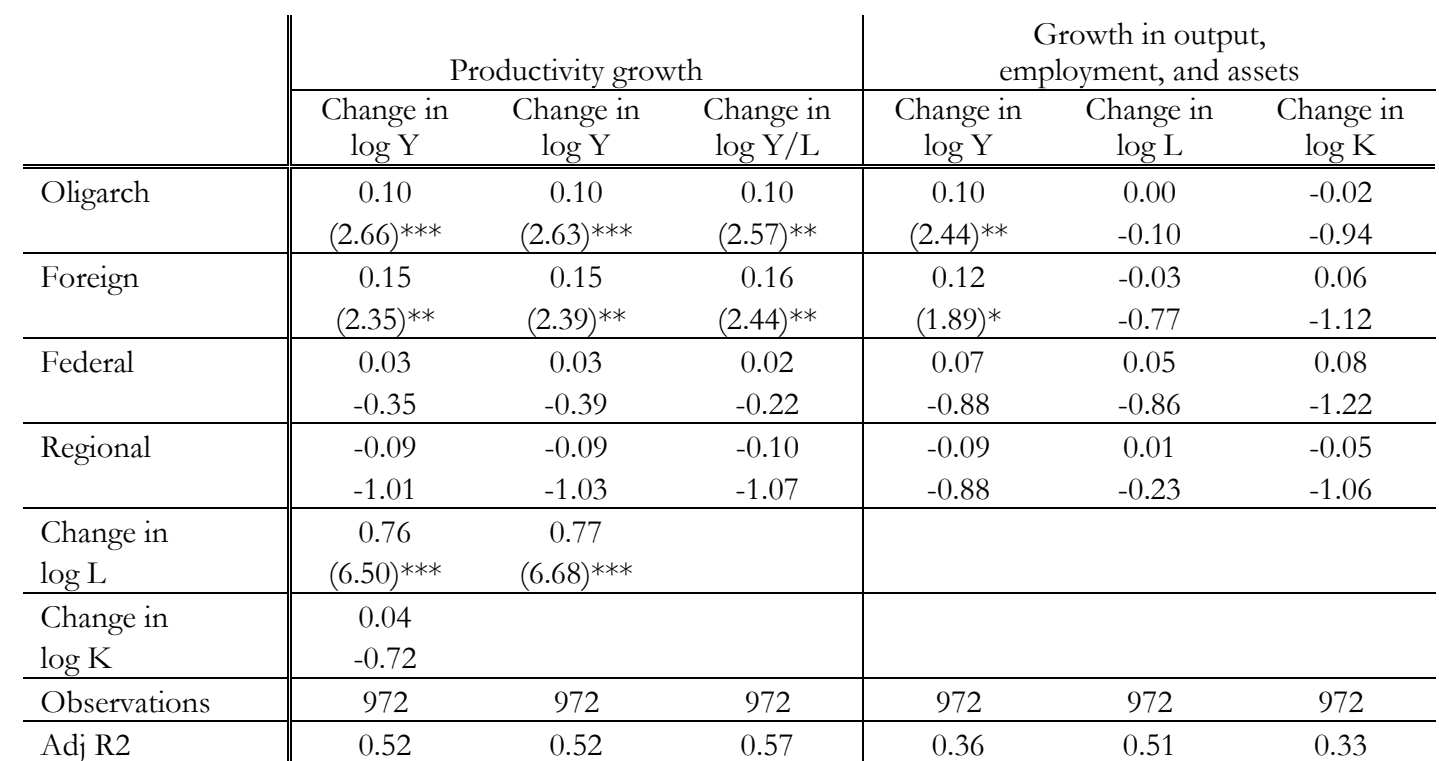

* significant at $10 \%$; ** significant at $5 \%$; *** significant at $1 \%$. Robust $t$ statistics in parentheses. The definition of control is based on the type of largest controlling stake holder given that the stake is at least $25 \%$. The omitted category is "other private domestic owner", dummy for "no controlling owner" included but not reported. Dummy variables for regions and industries are included. Outliers: 1\% highest and 1\% lowest observations of $\log \left(Y_{i, 2002} / Y_{i, 2001}\right), \log \left(K_{i, 2002} / K_{i, 2001}\right)$, and $\log \left(L_{i, 2002} / L_{i, 2001}\right)$ are excluded.

\section{Table 5. Oligarchs have higher profits and pay similar wages.}

\begin{tabular}{|c|c|c|c|c|c|c|c|}
\hline & \multicolumn{3}{|c|}{ Productivity levels } & \multicolumn{4}{|c|}{ Profits and wages } \\
\hline & $\log \mathrm{Y}$ & $\log \mathrm{Y}$ & $\log \mathrm{Y} / \mathrm{L}$ & $\begin{array}{c}\text { Profit/ } \\
\text { Sales } \\
\end{array}$ & $\begin{array}{c}\text { Profit/ } \\
\text { Sales } \\
\end{array}$ & log wage & log wage \\
\hline \multirow[t]{2}{*}{ Oligarch } & -0.10 & -0.17 & -0.19 & 0.13 & 0.11 & 0.01 & 0.04 \\
\hline & -1.31 & $(2.09) * *$ & $(2.41)^{* *}$ & $(3.18)^{* * *}$ & $(3.01)^{* * *}$ & -0.31 & -1.61 \\
\hline \multirow[t]{2}{*}{ Foreign } & 0.27 & 0.46 & 0.45 & -0.01 & 0.01 & 0.33 & 0.17 \\
\hline & $(1.81)^{*}$ & $(3.02)^{* * *}$ & $(2.97)^{* * *}$ & -0.15 & -0.30 & $(4.18)^{* * *}$ & $(2.97)^{* * *}$ \\
\hline \multirow[t]{2}{*}{ Federal } & 0.20 & 0.10 & 0.13 & 0.05 & 0.04 & 0.08 & -0.02 \\
\hline & -1.36 & -0.68 & -0.86 & -0.72 & -0.71 & -1.28 & -0.36 \\
\hline \multirow[t]{2}{*}{ Regional } & -0.22 & 0.15 & 0.15 & -0.03 & -0.04 & 0.04 & 0.04 \\
\hline & -1.25 & -0.87 & -0.91 & -0.32 & -0.46 & -0.59 & -1.01 \\
\hline \multirow[t]{2}{*}{$\log L$} & 0.75 & 1.05 & & & & 0.03 & 0.02 \\
\hline & $(13.08)^{* * *}$ & $(30.13)^{* * *}$ & & & & $(2.39) * *$ & -1.44 \\
\hline $\log K$ & $\begin{array}{c}0.28 \\
(7.97)^{* * *}\end{array}$ & & & & & & \\
\hline $\log \mathrm{Y}$ & & & & $\begin{array}{c}0.07 \\
(5.10)^{* * *}\end{array}$ & $\begin{array}{c}0.07 \\
(4.76)^{* * *}\end{array}$ & & \\
\hline $\begin{array}{l}\text { Profit/Sales } \\
\text { lagged }\end{array}$ & & & & & $\begin{array}{c}0.02 \\
-0.48\end{array}$ & & \\
\hline log wage & & & & & & & 0.57 \\
\hline lagged & & & & & & & $(4.95)^{* * *}$ \\
\hline Obs. & 1026 & 1122 & 1122 & 1067 & 1048 & 1193 & 1183 \\
\hline Adj R2 & 0.87 & 0.85 & 0.59 & 0.35 & 0.39 & 0.55 & 0.78 \\
\hline
\end{tabular}

* significant at $10 \%$; ** significant at $5 \%$; *** significant at $1 \%$. Robust t statistics in parentheses; dummy variables for regions and industries included. The omitted category is "other private domestic owner", dummy for "no controlling owner" included but not reported. Dummy variables for regions and industries are included. $1 \%$ highest and $1 \%$ lowest observations of dependent variables are excluded. 
The results are to be treated with caution. First, we can only provide evidence on one year. More data are to be collected, and at least the performance of these firms should be tracked for years to come. Second, the quality of accounting data is problematic. This is especially important for our measure of capital based on the book value of assets. It suffers from many problems inherent to Russian accounting system. However, our results are robust to excluding capital. Oligarchs and foreign owners still outperform others in terms of productivity. Yet, if we are not certain of the quality of capital variable, we cannot say whether superior performance of is driven by their higher productivity or because they invest more. There is also a potential misreporting issue related to transfer pricing. Worldbank (2004) establishes that the problem of underreported output or inflated costs is important at least at the macro level. However, this is not a problem as long as the degree of transfer pricing would be different across ownership categories given industry and region (and size of the firm). Moreover, for TFP growth regressions, it is sufficient that the degree of misreporting would change over time in similar way for different owners.

Third, even controlling for industry and regions there can be a selection bias. It may well be the case that oligarchs have acquired assets with higher productivity growth potential. To resolve this issue, more data are needed, in particular, we need more than one observation on ownership structure for each firm.

Finally, we cannot distinguish whether oligarchs outperform other owners because they are better managers or because they are politically connected. 


\section{Privatization, ownership concentration and property rights}

The evidence above is consistent with the view that Russian privatization has indeed shifted control over industry to large private owners (either outsiders or efficient insiders) that are successfully restructuring their companies. On the other hand, the emergence of oligarchs has been associated with an increase in inequality and concentration of ownership. While ownership concentration and inequality are per se costly for institutional development and economic growth, in Russia the emergence of oligarchs has also been accompanied by the problem of illegitimacy of private property rights. The public attitude towards the oligarchs is so negative that any politician accountable to the median voter would have to confiscate their property. In the July 2003 poll by ROMIR, 88\% responded that all large fortunes were amassed in an illegal way, and 57\% agreed that government should launch criminal investigations against the wealthy (Vedomosti, 2003b). In Aug 2001 VCIOM poll, 72\% Russians said that the "best thing to do now about past privatization" is to "investigate all past wrong-doing and return affected property to the state" (only 12\% agreed that "amnesty to strengthen property rights" is a good idea).

\section{Is ownership concentration in Russia too high by international standards?}

We are not aware of comparable datasets on non-listed firms, but there are data on the share of stock market capitalization controlled by ten largest families. Our calculations for Russian stock market in June 2003 provide a number of $60.2 \%$. This is much higher than in any country in continental Europe here the share of 10 largest families is below 35\% in small countries, and 30\% in all large countries (Faccio and Lang, 2002). In the US and the UK this share is in single-digit percentages (Faccio and Lang, 2002, Claessens et al, 2002). ${ }^{11}$

Russia's concentration is also higher (although not much higher) than in any East Asian country before 1997 crisis; according to Claessens et al. (2000), the highest shares of 10 largest firms were in Indonesia (58\%), Philippines (52\%), Thailand (43\%) and Korea (37\%). The numbers for Indonesia and Philippines include the holdings of Suharto and Marcos families, each controlling $17 \%$ total market capitalization in the respective countries. In Russia, the personal wealth of Yeltsin and Putin is considered to be very modest.

But even these comparisons underestimate the role of oligarchs. Indeed, in Europe and East Asia, separation of ownership and control and dispersed ownership allows largest family to exercise

\footnotetext{
${ }^{11}$ A less rigorous approach is to look at Forbes' billionaires lists. Even though Russian companies are significantly undervalued compared to their OECD counterparts, Forbes (2004) lists 26 billionaires in Russia (only the US and Germany have more). The 26 Russian billionaires are worth $\$ 81$ billion, or 19\% Russia's annual GDP. The 26 richest US citizens are worth 4\% US GDP; the total wealth of all 275 US billionaires is below $7 \%$ GDP.
} 
control with a relative small ownership stake in the respective companies (both Faccio and Lang and Claessens use the threshold of 20\%). In Russia, the largest groups hold majority and supermajority shares of both control and cash flow rights (Guriev and Rachinsky, 2004, Boone and Rodionov, 2002).

Thus, ownership concentration in modern Russia is probably the highest in the world, at least among the countries with available data.

\section{Emergence of concentrated ownership and legitimacy of property rights}

The emergence of huge conglomerates within just a decade is certainly an extraordinary event. Since the goal of privatization was to create a broad class of owners (Boycko et al, 1995), concentration of more than a third of Russian industry in the hands of twenty groups begs for an explanation.

In the hindsight, the rise of oligarchs was unavoidable given the sequencing of Russian reform. In the beginning of 1990s Russia lacked all capitalist institutions. The reformers opted for rapid privatization, as they presumed that without privatization, there will be no constituencies for the institutional change (Boycko et al, 1995, Aslund, 2004). Therefore the privatization happened in the environment with high returns to scale and political connections. Indeed, the important role of the state and imperfect legal system created huge private benefits of control and the value of political clout and therefore of sheer size. Hence the property rights were eventually concentrated in the hands of a few large owners rather than a broad base of small owners. Even if originally privatized to dispersed shareholders, the ownership structure quickly consolidated through dilution and, in some cases, outright expropriation of outside investors including government (Boone and Rodionov, 2002). The current champions of transparency Mikhail Khodorkovsky and Vladimir Potanin (now chairing Russia's National Council for Corporate Governance) kept expropriating outsiders until as recently as 1999 (Black, 2001, Dyck, 2003).

The most important problem of Russian oligarchic capitalism is that privatization has not created secure property rights. Russian voters still do not fully recognize the legitimacy of privatization. In July 2003 poll, 77\% Russians said that privatization results should be partially or fully reconsidered (Vedomosti, 2003). There seems to be little doubt that a referendum on renationalization of natural resource industries would produce a landslide 'yes.' ${ }^{12}$

12 In 2002, pro-Kremlin parties have consolidated enough power in Russian parliament to take all parliamentary committees away from Communists. In retaliation, the Communists proposed to hold a referendum that included questions on renationalization of natural resources. The pro-Kremlin majority immediately passed a law that ruled out any referenda within one year from election date (which effectively shut down the Communist referendum). The sense of urgency to prevent the referendum was so high that the parliament kept voting on the issue continuously until the required supermajority was achieved; it took four consecutive votes on Sep 20, 2002 (Moscow Times, 2002). 
The attitude of Russian voters towards privatization was not always negative. Indeed, in 1991 presidential elections Boris Yeltsin got an overwhelming mandate for reforms. Shiller et al. (1991) reported that Russians' attitude to market in 1990 was not significantly different from that of Americans. However, most Russians believe that they received nothing in the course of voucher privatization. Effectively, most Russians only got $\$ 10-20$ for their vouchers if they sold it, and many got even less expropriated by fraudulent investment funds. ${ }^{13}$ Therefore the whole Russian population got from privatization about as much as the single richest Russian individual (Forbes, 2004). In VCIOM’s August 2001 poll, 68\% Russians say that privatization resulted in a net loss for them while only $5 \%$ said that they gained.

The risk of illegitimacy was well understood by the reformers or at least by their advisors very early on. Boycko et al. (1995, p. 60) warned about the costs of spontaneous privatization "... Nor is the public usually happy about the massive theft of public assets. Politically, then, spontaneous privatization is very costly to reformers." Yet, reformers chose to take this bet. In 1994, Russian privatization czar Anatoly Chubais complained to his colleague about Russia's leading businessmen "They steal and steal and steal. They are stealing absolutely everything and it is impossible to stop them. But let them steal and take their property. Then they will become owners and decent administrators of this property." (Financial Times, 1996).

Unfortunately, owners have incentives to invest only if their property rights are accepted by public. In Russia, any incumbent politician can threaten oligarchs with expropriation since the latter would be supported by a vast majority of voters. This threat was essential to enforcement of the pact between Putin and the oligarchs (allegedly agreed upon in the meeting on July 28, 2000) where Putin promised not to revisit privatization if oligarchs supported his efforts to consolidate political power and pay taxes. ${ }^{14}$ The threat was proven credible in 2003. As Mikhail Khodorkovsky deviated from the pact by openly criticizing corruption in Putin's administration, supporting opposition parties and independent media, he and his partners were either arrested or forced into exile. ${ }^{15}$

\footnotetext{
13 The vouchers were so cheap because the assets were privatized a bargain prices. Again, lack of institutions resulted in collusion in auctions, as well as buyers' financial constraints. Another important reason was effective exclusion of foreigners. While most oligarchs had a pro-Western orientation, they benefited from the lack of foreign competition; some were active in deterring foreign participation. In a conversation with a Western journalist, Khodorkovsky's deputy took pride in authoring the laws that kept foreigners away from privatizing Yukos, (Freeland, 2000, p. 185). Low privatization prices are not uncommon in other countries: as Megginson and Netter (2001) report, there is evidence on excess returns on privatization IPOs around the world.

${ }^{14}$ There was never a written pact but it was common knowledge that an informal agreement was reached. A poll by FOM a week after the meeting showed that 57\% Russians knew about the pact. $37 \%$ believed that Putin would stick to the pact (vs 30\% who did not), and 71\% believed that oligarchs would not observe their promises (vs $10 \%$ who thought they would).

${ }^{15}$ Khodorkovsky and his partners supported all major opposition parties, Vedomosti (2003b). It is not clear why
} 


\section{Oligarchs' futures}

The discussion above raises a number of non-trivial questions. Can and should Russia draw a line over the tumultuous 1990s or the legacies of privatization will prevent its economy from growth and development in coming years? If yes, what exactly should be done?

In the past, quite a few oligarchic economies have generated high growth rates, at least for substantial periods of time. The examples of Korean chaebols, Japanese zaibatsu, Swedish and Italian family controlled firms show that oligarchic economies can be successful; even though they are vulnerable to crises. The latter can come either from a generational change in conglomerates' leadership or from inherent inflexibility and tendency to suppress entry of new businesses. The former factor has been important in the decline of many family controlled businesses in Italy (Aganin and Volpin), Sweden (Hogfeldt, 2003), and Korea (Graham, 2003). At the time of retirement, the founders of family controlled firms face a tough dilemma of either hiring a professional manager and thus separating ownership and control or passing control to a less competent heir (Burkart et al., 2003). However, Russian oligarchs are young, so the generational change is rather irrelevant.

The other problem with oligarchic economies is that they usually erect barriers to entry (Acemoglu, 2003) either through suppressing financial development (Rajan and Zingales, 2003, Perotti and Volpin, 2003) or through superior access to political resources. This risk is certainly very important for Russia where the growth potential of oligarchs' natural resource industries is certainly limited in the long run, and new entry in other sectors is crucial for sustainable development.

It is not clear what is going to happen to Russian oligarchs. Below we formulate three possible policy scenarios. We first consider a "status quo" scenario where there are no significant policy changes. The second scenario is the one where the government takes a tougher stance on oligarchs and confiscates their assets. Then we discuss a scenario where government tries to engineer an amnesty. After formulating the three scenarios that differ with regard to oligarchs' property rights, we discuss another policy dimension: lowering entry barriers for non-oligarch entrepreneurs through financial development, competition and openness.

We evaluate the scenarios on the basis of economic efficiency only but also take into account political feasibility. In terms of economic theory, Russia needs to design a mechanism which will provide incentives to invest in productivity to those in control of industrial assets; at the same time

Khodorkovsky did not stick to the pact. Most likely, asymmetric information played a role (as modeled in Braguinsky and Myerson, 2003, the paper that was written before the crackdown). When in the sixth meeting of RSPP with Putin (Feb 2003), Khodorkovsky complained about corruption in the government, he probably did not expect Putin to respond questioning-in public-the legitimacy of Khodorkovsky's 1990s appropriations (Moscow Times, 2003). 
this mechanism should be renegotiation-proof, whoever is in power should be able commit to this mechanism along the equilibrium path. ${ }^{16}$

The key players include the oligarchs, the ruling bureaucracy and the public. Public has no political weight, but its interests can be represented by the President accountable to the median voter. Our analysis is somewhat similar to the one in Acemoglu (2003). Acemoglu emphasizes the trade-off between oligarchy where the rule by rich elite results in low taxes but high entry barriers and populist democracy where median voter raises redistributive taxes but also keeps entry barriers low; Acemoglu discusses but exogenously rules out the outcome where bureaucracy is in control (predatory state). In what follows, the political regime is a convex combination of three extreme outcomes: oligarchy, predatory state, and populist democracy with relative weights determined by the policies pursued.

\section{Status quo}

Khodorkovsky's imprisonment has removed any remaining doubts in Kremlin's resolve to punish deviations from the 2000 pact. Therefore oligarchs will respect the pact and will not interfere in national politics. In a sense, Putin has pursued the "political antitrust" policy that was crucial in building US democracy and economy in the beginning of $20^{\text {th }}$ century (Rajan and Zingales, 2003). Even though oligarchs remain economically powerful, they have no longer any weight in politics. However, Khodorkovsky's case has also made the oligarchs too vulnerable. Given that bureaucracy is as corrupt as before, this effectively shifted the bargaining power from oligarchs to bureaucrats. Although outright expropriation of oligarchs will probably remain just a threatpoint, their cash flows will be intensively milked by bureaucrats. This will in turn undermine oligarchs' property rights and incentives to invest.

In order to sustain growth in this scenario, Putin has to reestablish his commitments under the pact. In particular, he has to constraint rent-seeking by the bureaucrats. It is certainly not an easy task given that democratic checks and balances are very weak. Moreover, neither government nor oligarchs are interested in the development of democracy and civil society. Bureaucrats do not like to cede their control, while oligarchs are afraid of median voter's redistributive agenda.

Putin's task is difficult but not impossible. It is instructive to look back at Park Chung-hee's first years in power in Korea. While there are many differences between Korea in the 1960s and Russia, it

\footnotetext{
${ }^{16}$ Even the short history of Russia's transition contains a number of examples proving the importance of commitment and political constraints. Boris Berezovsky was one of the key figures behind Vladimir Putin's ascent to power. Yet, after Putin was elected, he did not respect Berezovsky's business interests or political views. The popular mandate has provided Putin with opportunity to prosecute Berezovsky (who was deeply disliked by voters) and get rid of whatever pre-election promises he made to Berezovsky.
} 
is certainly not true that corruption was initially low in Korea. Nor did Korea possess developed democratic institutions. General Park came to power in 1960 after Korean public was deeply disappointed in the corrupt regime of Syngman Rhee, the first president of independent Korea. At that time chaebol owners have already built their initial wealth; public deemed their wealth illegitimate as it was related to corrupt deals and misuse of US aid (Graham, 2003). General Park started off with a crackdown on these "oligarchs". He even made them promise to donate large parts of their wealth to charities or return to the state. Korea's richest person, Lee Byung-chol of Samsung (who supposedly held 19\% of all national wealth, Graham, 2003) was in opposition to Park and eventually had to pay fines to government in 1963. Yet, no chaebol lost any serious part of its wealth. No chaebol leader was prosecuted, even though Park's new laws certainly allowed that and twenty four arrests were initially made to establish credibility. In Park's later years, chaebols have received a substantial support from the state in the form of subsidizied loans. The support was awarded mostly to those who succeeded in the export markets. Apparently, Park's administration was happy with chaebols as long as they led Korea's industrialization and economic growth.

There are two important problems with the Korean scenario for Russian voters and Russian rulers. First, it does illustrate that democracy may take a very long time to emerge along this path. After losing popularity, Park Chung-hee first rigged an election, and then cancelled presidential elections, appointing himself a president for life. He was assassinated by his own security chief in 1979.

The second problem is that part of Korea's success was an ingenious winner picking by Park. Against all odds and economists' advice he promoted specific industries where Korea did manage to get a market niche. It is hard to reproduce this strategy now as Russia is no longer in the industrialization stage, and global competition is much tougher. However, this should not be a concerns, as oligarchs are able choose profitable market strategies themselves.

\section{Confiscation}

Confiscation of oligarchs' property and prosecution of oligarchs is certainly the most popular option with Russian public. There seems to be little doubt that in modern Russia government can expropriate and prosecute oligarchs. It is less clear though what would happen with the assets after confiscation. There can be two approaches: one is to simply renationalize them and manage as a public company, the other one is to auction them off again. Both are problematic. The assets currently controlled by oligarchs can and should be run by private owners; there are no externalities or public good arguments involved, and the inefficiency of Russia's public companies is notorious. 
Selling the confiscated assets to other private owners may not succeed in building legitimacy of property rights. Indeed, suppose that the auctions are not open to foreign strategic investors. Given financial underdevelopment, the only buyers who can offer a high price are other oligarchs. ${ }^{17}$

Certainly, government may exclude other oligarchs (or expropriate all the oligarchs simultaneously). The others buyers will be financially constrained and will necessarily pay a very low price. Therefore the new owners' property rights will also be at least partially illegitimate. Russian public will know that they have bought the assets at the fraction of the value. Moreover, given Russia's institutional environment, the new owners will quickly learn that "size matters" and consolidate into oligarchs themselves.

It is also not clear whether the government will be able to run the auctions honestly. A very recent example of Slavneft privatization shows that collusion between bidders (and, possibly, between bidders and auctioneers) is as common in Putin's Russia as it was in Yeltsin's (Financial Times, 2002b). In Dec 2002, a large state owned oil asset was sold at a price slightly above the reserve price, with competing bids (including ones by foreigners) either discouraged or excluded on technical grounds. Rigging the auctions will further reduce the price and therefore legitimacy of subsequent property rights.

The confiscation will therefore just reproduce a new generation of oligarchs whose incentives to invest will not necessarily be stronger.

An interesting example of breaking up conglomerates by force is the story of Japan's zaibatsu that are in many ways similar to Russian largest conglomerates (Morikawa, 1992). In 1945, US occupation authorities accused zaibatsu's controlling families of supporting Japanese militarism and ordered dissolution of zaibatsu (Miwa and Ramseyer, 2003). Effectively, zaibatsu's owners were expropriated, and their individual firms were mostly bought by incumbent management. However, already by 1958, zaibatsu re-emerged in the form of keiretsu (Bergloef and Perotti, 1996, Miwa and Ramseyer, 2003). Although keiretsu were not as centralized as zaibatsu (where all firms within a conglomerate were controlled by a single family), they engaged in cross-shareholding and coordinating their activities; firms that were part of a zaibatsu now joined the keiretsu that was built in place of this particular zaibatsu.

This experience suggests that the size and composition of conglomerates does depend on institutional environment and market conditions. Hence, if oligarchs' empires are broken off and sold by piece, they are likely to reemerge as unified groups albeit controlled by new owners.

\footnotetext{
${ }^{17}$ When Berezovsky went into exile, his assets were purchased by Abramovich. When Abramovich started moving to London, his assets were bought by Deripaska. In July 2003 poll by VCIOM, only $10 \%$ respondents believed that confiscated assets will benefit the public, the most popular responses were that the assets will be appropriated by other oligarchs $(31 \%)$, state $(24 \%)$, bureaucrats $(23 \%)$, and organized crime $(18 \%)$.
} 
Confiscation can only work if the assets are sold in honest auctions open to foreigners. Ruling bureaucracy will certainly try to prevent this from happening, as this will result in their loss of control over the assets and cash flows. In order to do so, the predatory state will masquerade as populist democracy and appeal to the median voter's nationalist sentiment.

\section{Amnesty}

A direct application of Coase theorem to the problem of illegitimacy of property rights provides a seemingly straightforward solution. The property rights should be clearly defined and awarded to a party that is willing to pay the most. Since the current oligarchs seem to be a good match for the assets, and they are also the only ones who are financial unconstrained, they should keep their assets but compensate others. This solution-known as a privatization amnesty- has been advocated by both critics of the reform (Goldman, 2004) and oligarchs themselves (Deripaska, 2004). There are many possible versions of the amnesty, but the most general approach could be the following. Russian government passes a federal law on statute of limitations granting property rights to anyone who acquired them at least $T$ years ago. In exchange, oligarchs make a lumpsum payment to the public.

There are many technical problems: (i) how much the oligarchs should pay; (ii) which oligarchs should pay; (iii) how the payment should be structured to avoid strangling oligarchs' companies; (iv) how to make sure payments reach out to public rather than get appropriated by corrupt bureaucrats; (v) how the statute of limitations be structured.

These problems are not impossible to solve. The dominant view is that the payment should be proportional to the current value of the oligarchs' assets (Deripaska, 2004, suggests 75-80\%). The assets' value could be self-assessed; there should be a provision that outside bidders (including foreigners) can buy out the assets at self-declared value times a pre-specified factor; this multiplier should be sufficiently low to encourage truthful revelation but not too low, and certainly above 1 , so that truthfully revealed value is not taken over easily. ${ }^{18}$ The participation in the program should certainly be voluntary for the oligarchs - those who have done no wrong, do not have to pay. Yet, the voluntary participation will only work if the other party's commitment to amnesty is perfect. Indeed, the very fact of an oligarch's participation in the amnesty provides a signal to the public that the particular oligarch is afraid of prosecution. So if there is risk of reneging on the amnesty, the primary targets of prosecution will be exactly the oligarchs participating in the amnesty.

\footnotetext{
${ }^{18}$ This and many other ideas in this section were suggested to authors by Luigi Zingales in private communications.
} 
The problem of structuring the payment is certainly more difficult. From the macroeconomic point of view, the oligarchs could simply redeem some of Russia's sovereign debt. However, in this case the payment will not reach the median voter; rather, this arrangement will soften government's budget constraints by allowing new debt issues; and higher government spending is not necessarily good for a median Russian. A more appealing alternative is to take responsibility for some of Russia's pension obligations, as pensioners are the ones who suffered the most in 1990s. The back of envelope calculations provide an estimate of about 3 average annual pensions. Indeed, the total oligarchs' wealth is in the range of $\$ 80$ billion (Forbes, 2004) and there are about 40 million pensioners in Russia, hence using Deripaska's $75 \%$ tax, we arrive at the total of $\$ 1,500$ per person. Certainly, the compensation cannot be made overnight (this would destroy oligarchs' companies). There should be a fund that would finance either annuity payments or lumpsum payments to the oldest pensioners. The deal may also be accompanied by a reduction in pension tax to spread part of the benefit to the working population.

It is much less clear what the oligarchs would get in exchange for the payment. The contract is inherently incomplete. Indeed, while the statute of limitations on privatization can be enforced, it is hard to keep away from prosecuting oligarchs on charges of tax fraud or other wrongdoings. Even if one assumes commitment on the part of the President in office, the new President can again appeal to public's negative attitude and return to confiscatory policies. Notice that the latter do not have to be as drastic as expropriation of property. Confiscation of value can simply occur through raising taxes on natural resource industries.

Hence, it is not clear how government and public can commit to the amnesty. Yet, there are examples of similar deals that did succeed. In 1938, Swedish social-democratic government introduced a new tax code. In exchange for higher income taxes (and pro-labor laws and regulations previously introduced), Swedish tycoons received very generous tax breaks on investments which gave large firms a serious advantage over new entrants (Hogfeldt, 2004). The deal has effectively been in place until 1990s.

\section{Competition and financial development}

All the scenarios above fail to address Russia's fundamental problem of institutional economies of scale. Institutions must be reshaped to encourage entry and growth of Russia's smaller businesses. Otherwise the economy will remain dominated by oligarchs, whether there is a shift towards amnesty or confiscation. The solutions are well-known: financial development, openness, competition policy (Rajan and Zingales, 2003). On top of the changes in economic institutions, legal and political environment must be reformed to eliminate economies of scale due to rent-seeking. The reform of the judiciary, creation of grass-roots political parties, and fighting corruption at all 
levels of bureaucracies are required. Taxes should be transparent and sufficiently low so that legitimate business operations are feasible.

As appealing this set of reforms is, it is virtually impossible to implement. Oligarchs are not interested in creating competition in product and factor markets, bureaucrats do not want to relinquish their power either, and other constituencies have little political power.

This is why in many oligarchic countries it took decades before financial revolution has started. In Italy and Sweden, the regime change was triggered by European integration (Aganin and Volpin, 2003, Hogfeldt, 2004), in Korea, it took a major crisis of 1997 to start the reform. However, there are also examples of success, most importantly - the US experience in the $20^{\text {th }}$ century.

The initial conditions in the US were not any better than those in modern Russia. In 1900, 22 tycoons had wealth that would be equivalent to today's $\$ 1$ billion (in terms of GDP per capita) or more, and their economic power was even higher than their relative wealth would suggest (De Long, 1998). These individuals were corrupt and ruthless. While they built their business empires from scratch they also got substantial resources from public coffers in the form of land grants (Aslund, 2004) or direct subsidies (De Long, 1998). Many US private railroads (the sector crucial for the rise of the most robber barons) were built with 100\% public funding. Moreover, some tycoons even managed to inflate the subsidies. Collis Huntington and Leland Stanford were supposed to receive government subsidies for construction of transcontinental railroad at the rate of USD 16,000 per mile of track in the flat terrain but 32,000 in foothills and 48,000 in the mountains; they have managed to claim mountain and foothill rates in flat areas (Stone, 1956).

The attitude of US public towards the robber barons was also quite similar (if not worse) as that of Russians towards the oligarchs. Both government and Congress were very corrupt. Also, in the beginning of $20^{\text {th }}$ century, US lagged behind other Western countries in terms of terms of financial development (Rajan and Zingales, 2003); the level of financial development in the US in 1913 was similar to that of modern Russia.

Yet, US have managed to rein in the "malefactors of great wealth" (as Theodore Roosevelt referred to the tycoons) and build a competitive economy and a highly sophisticated financial system. Antitrust policies, higher taxes to finance war and the rising welfare state, and Glass Steagall Act have substantially reduced their relative role in the US economy and politics (De Long, 1998). It has taken a long time for the US to get to where it is now; moreover US success can be explained by the common law system and a strong middle class that Russia lacks. Yet, Russia may cover this path faster. First, we now understand better what needs to be done; in particular, how to reform and regulate banking and securities markets. Also, the $20^{\text {th }}$ century's progress was slowed down by two World Wars and the Great Depression. Second, Russia can leapfrog certain stages by importing 
competition and financial development. Russia should open up to foreign banks (which is currently fiercely opposed by Russian banking community), to imports and to foreign investors (which is going to happen once Russia joins WTO). Third, the "political antitrust" has effectively succeeded the 2000 pact rules out the risk of hijacking the political process by even very rich individuals. On the other hand, there remains a powerful opposition to financial development, competition and openness coming from bureaucracy that certainly prefers the existing system.

\section{Conclusions}

Both negative and positive stereotypes on Russian oligarchs are true. They do control a substantial part of the economy including natural resources industries. The concentration of ownership in modern Russia is probably higher than in other countries. Moreover, it is likely to increase further as Russian's natural monopolies are being reformed and privatized. Oligarchs seem to run their empires more efficiently than other Russian owners. Also, while the relative weight of their firms in Russian economy is huge, they do not seem to be excessively large by the standards of the global economy where most of them are operating. We cannot judge whether they acquired their assets in a illegitimate way, but majority of Russian population certainly believes so which creates a fundamental problem for building a democratic and prosperous Russia.

This problem is neither insurmountable, nor unique to Russia. Quite a few countries have managed to overcome the burden of high ownership concentration. It is not easy, and it may take a long time. All the scenarios of development that we sketched in this paper are painful, and in each of them success is not guaranteed. Which scenario is most likely to occur? In Russia's highly centralized political system, a lot depends on the preferences and actions of the President. Yet we conjecture that Russia will follow a mix of "status quo" and "amnesty". The recent crackdown on oligarchs has greatly increased bureaucrats' bargaining position with regard to large business. So the oligarchs are now better off starting to pay higher taxes rather than continue to be blackmailed and therefore milked by bureaucracy. Certainly, corrupt bureaucrats prefer bribes to taxes, but by advocating higher taxes and transparency, oligarchs can circumvent the bureaucrats by directly appealing to voters. This should also build up legitimacy over time while in the status quo scenario oligarchs remain illegitimate forever.

An unpleasant implication of this analysis is that the development of democracy in Russia may take a long time. Countries with concentrated ownership have lived with " $1 \frac{1}{2} 2$ party system" for decades. The real competition between strong political parties is more likely to emerge when financial development, competition policies and openness lower entry barriers and promote the rise of middle class. Neither oligarchs nor the bureaucracy seem to be interested in implementing these policies in Russia anytime soon. 


\section{References}

Acemoglu, Daron. 2003. "The Form of Property Rights: Oligarchic vs. Democratic Societies." Mimeo, MIT Department of Economics.

Aganin, Alexander, and Paolo Volpin. 2003. History of Corporate Ownership in Italy. Mimeo, LBS. Aslund, Anders. 2004. “The Misguided Blame Game.” Transition Newsletter, Vol. 14/15, p. 25-26.

Barca, Farizio, and Marco Becht, ed. 2001. The control of corporate Europe. NY: Oxford University Press.

Becht, Marco. 1999. "European Corporate Governance: Trading-Off Liquidity Against Control.” European Economic Review, 43:1071-83.

Berglöf, Erik, and Enrico Perotti. 1994. "Corporate Governance Structure of the Japanese Financial Keiretsu," Journal of Financial Economics, 36, pp. 259-284.

Black, Bernard. 2001. "The Corporate Governance Behavior and Market Value of Russian Firms", Emerging Markets Review, 2, pp. 89-108

Blanchard, Olivier, and Michael Kremer. 1997. "Disorganization.” Quarterly Journal of Economics, 112(4), 1091-1126.

Boone, Peter, and Denis Rodionov. 2002. "Rent seeking in Russia and the CIS" Brunswick UBS Warburg, Moscow.

Boycko, Maxim, Andrei Shleifer, and Robert Vishny. 1995. Privatizing Russia. MIT Press.

Braguinsky, Serguey, and Roger Myerson. 2003. “Oligarchic Property Rights And Investment.” Mimeo, SUNY Buffalo.

Burkart, Mike, Fausto Panunzi and Andrei Shleifer. 2003. "Family Firms.” Journal of Finance, 58: 2173-2207.

Claessens, Stijn, Simeon D. Djankov, and Larry H.P. Lang. 2000. “The Separation of Ownership and Control in East Asian Corporations", Journal of Financial Economics, Vol. 58, No 1-2, pp. $81-112$.

De Long, J. Bradford. 1998. "Robber Barons", in Anders Aslund, ed., Perspectives on Russian Economic Development (Moscow: Carnegie Endowment for International Peace).

Deripaska, Oleg. 2004. "Beating Poverty Through Equal Opportunities.” Moscow Times, Feb 18, 2004.

Dyck, Alexander. 2003. "Hermitage Fund, The: Media and Corporate Governance in Russia." Harvard Business School Case 703-010. 
Dynkin, Alexandr and Alexei Sokolov. 2002. "Integrated Business Groups in Russian Economy." Voprosy Ekonomiki, 4, 78-95. [In Russian]

Faccio, Mara, and Larry H.P. Lang. 2002. “The ultimate ownership of Western European Corporations." Journal of Financial Economics, 65, 365-395.

Financial Times. 1996. Moscow's Group of Seven. Nov 1, 1996, p.17.

Financial Times. 2002a. Putin's bid to join WTO splits business - Russia's oligarchs seek to protect their interests from foreign encroachment, March 27.

Financial Times. 2002b. Sale of Russian oil group leaves questions over fairness, Dec 19, 2002, p.6.

Forbes. 2004. The World's Richest People, Feb 26, 2004.

Forbes Russia. 2004. Russia’s 100 Richest People, May 13, 2004. [In Russian]

Freeland, Chrystia. 2000. Sale of the Century: Russia's Wild Ride from Communism to Capitalism. NY: Crown Business.

Goldman, Marshall. 2004. “The Rule of Outlaws is Over.” Transition Newsletter, Vol. 14/15, p. 2325.

Graham, Edward. 2003. Reforming Korea's Industrial Conglomerates. Institute for International Economics, Washington, DC.

Grossman, Gene, and Elhanan Helpman. 1994. "Protection for Sale", American Economic Review 84: 833-50.

Guriev, Sergei, and Andrei Rachinsky. 2004. "Ownership concentration in Russian industry." Worldbank, Background paper for Country Economic Memorandum for Russia.

Hoff, Karla, and Joseph Stiglitz. 2004. "After the Big Bang? Obstacles to the Emergence of the Rule of Law in Post-Communist Societies", American Economic Review, forthcoming

Hoffman, David E. 2003. “The Oligarchs.” NY: Public Affairs.

Hogfeldt, Peter. 2004. "The History and Politics of Corporate Ownership in Sweden.” Mimeo, Stockholm School of Economics.

Kommersant. 2003. Who owns Russia? Moscow: Vagrius. [In Russian]

Kumar, Krishna, Raghuram Rajan, and Luigi Zingales. 2003. 'What Determines Firm Size?" Mimeo, GSB, University of Chicago.

La Porta, Rafael, Florencio Lopez-de-Silanes, Andrei Shleifer, and Robert W. Vishny. 1998. "Law and Finance.” Journal of Political Economy, 106: 1113-1155. 
LaPorta, Rafael, Florencio Lopes de Silanes, Andrei Shleifer, and Robert Vishny. 1999. “Corporate

Ownership Around the World", Journal of Finance, 54: 471-517.

Latynina, Yulia. 2004. “Miscounted.” Ezhenedelnyi Zhurnal, May 18, 2004. [In Russian]

Megginson, William L., and Jeffry M. Netter. 2001. "From State to Market: A Survey of Empirical

Studies on Privatization" Journal of Economic Literature XXXIX, pp. 321-389.

Miwa, Yoshiro, and J. Mark Ramseyer. 2003. "Does Ownership Matter? Evidence from the Zaibatsu

Dissolution Program.” Journal of Economics and Managamnet Strategy, 12, 67-90.

Morikawa, Hidemasa. 1992. Zaibatsu: The Rise and Fall of Family Enterprise Groups in Japan. University of Tokyo Press.

Moscow Times. 2002. "Kremlin Bill Gets Lashing In Duma.” September 19, 2002.

Moscow Times. 2003a. “Tycoons Talk Corruption in Kremlin.” February 20, 2003.

Moscow Times. 2003b. "Foreign Used Car Prices May Rise Again.” April 22, 2003.

Pappe, Yakov. 2000. “The Oligarchs.” Moscow: Higher School of Economics. [In Russian]

Perotti, Enrico, and Paolo Volpin. 2004. "The Political Economy of Entry: Lobbying, Inequality and Financial Development.” Mimeo LBS.

PSI Foundation. 2003. Large Russian Business: A Digest of Corporate Statistics. Moscow. [n Russian]

Rajan, Raghuram G., and Luigi Zingales. 2003. Saving Capitalism from the Capitalists: Unleashing the Power of Financial Markets to Create Wealth and Spread Opportunity, NY: Crown Business.

Scharfstein, David, and Jeremy Stein. 2000. “The Dark Side of Internal Capital Markets: Divisional Rent-Seeking and Inefficient Investment,", Journal of Finance, 55, 2537-2564.

Schoar, Antoinette. 2002. "Effects of Corporate Diversification on Productivity", Journal of Finance LVII, 2379-2403.

Shiller, Robert J., Maxim Boycko, and Vladimir Korobov. 1991. "Popular Attitudes Toward Free Markets: The Soviet Union and the United States Compared" The American Economic Review, 81, 385-400.

Shleifer, Andrei and Daniel Treisman. 2004. “A normal country.” Journal of Economic Perspectives, this issue.

Slinko, Irina, Evgeny Yakovlev, and Ekaterina Zhuravskaya 2003, Laws for Sale: Evidence from Russian Regions, mimeo, CEFIR, Moscow. 
Sonin, Konstantin. 2003. "Why the Rich May Favor Poor Protection of Property Rights?”, Journal of Comparative Economics, 31, 715-731.

Stiglitz, Joseph. 2002. Globalization and Its Discontents. New York: W. W. Norton.

Stone, Irving. 1956. Men to match my mountains: the opening of the Far West 1840-1900. Garden City, N.Y., Doubleday.

Vedomosti. 2003a. "Khodorkovsky confessed: Yukos shareholders will support Union of Right Wing Forces, Yabloko, and the Communist Party.” April 8. [In Russian]

Vedomosti. 2003b. “Take away and divide: people's aspirations have not changed in 86 years." July 18. [In Russian]

Yakovlev, Evgeny, and Ekaterina Zhuravskaya. 2003. "State Capture and Controlling Owners of Firms.” Russia CEM 2003 background paper, CEFIR, Moscow.

Worldbank. 2004. From Transition To Development: A Country Economic Memorandum for the Russian Federation. Moscow. 